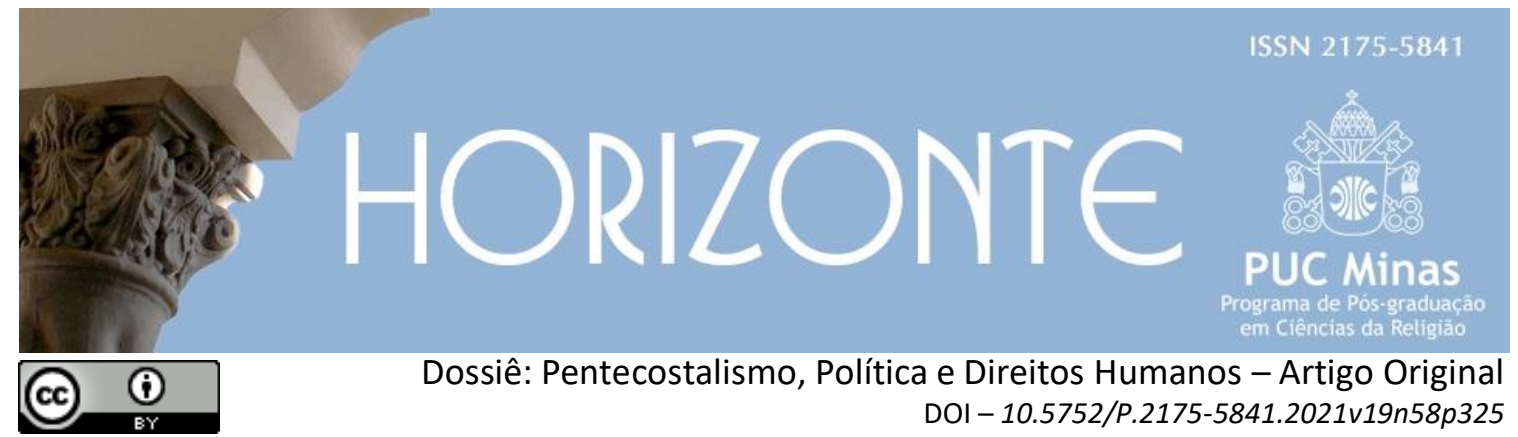

\title{
A teoria da revelação divina: uma interlocução com a teologia de Torres Queiruga para comunicar Deus hoje
}

\author{
The theory of divine revelation: an interlocation with the theology of \\ Torres Queiruga to communicate God today
}

José Aguiar Nobre*

\begin{abstract}
Resumo
O contexto eclesial da atualidade com todos os seus desafios geopolíticos e eclesiológicos, reivindica, uma maior compreensão das teorias da religião para uma Igreja em Saída. A Igreja conduzida pelo Magistério de Francisco favorece a percepção genuína de Deus que Jesus veio revelar. A sua forma de evangelizar constitui uma rica oportunidade para se colocar em prática os ensinamentos puros do Ressuscitado. Indaga-se: quais meios mais eficientes hoje para uma maior acolhida da mensagem revelada? Entende-se que a teoria da revelação divina produzida pelo teólogo galego, em sintonia com espírito do Vaticano II, quando bem compreendida tem sempre uma grande oportunidade de evidenciar a genuína imagem de Deus na contemporaneidade e de conquistar uma visibilidade universal. A hipótese é de que a sensibilidade do ser humano hodierno não suporta uma fé que esteja desconectada da sua realidade onde não há mais um nexo entre a fé revelada e a sociedade. Os resultados esperados apontam que a teologia da revelação de Andrés Torres Queiruga constitui um ponto de interlocução e uma rica mediação para comunicar Deus hoje, de modo que a perspectiva de eficácia evangelizadora frente à eclesiologia de Francisco atinja uma práxis renovadora.
\end{abstract}

Palavras-chave: Revelação. Torres Queiruga. Francisco. Imagem. Linguagem de Deus.

\begin{abstract}
The ecclesial context of today with all its geopolitical and ecclesiological challenges claims a greater understanding of the theories of religion for an outgoing Church. The Church led by the Magisterium of Francis favors the genuine perception of God that Jesus came to reveal. His way of evangelizing is a rich opportunity to put into practice the pure teachings of the Risen One. What are the most efficient means today for a greater acceptance of the revealed message? The theory of divine revelation produced by the Galician theologian, in harmony with the spirit of Vatican II, when well understood always has a great opportunity to highlight the genuine image of God in contemporary world and to gain universal visibility. The hypothesis is that the sensitivity of the human being today does not support a faith that is disconnected from its reality where there is no longer a connection between revealed faith and society. The expected results indicate that the theology of the revelation of Andres Torres Queiruga constitutes a pointed out as a point of interchange and a rich mediation to communicate God today, so that the prospect of evangelizing efficacy towards the ecclesiology of Francis reaches a renewing praxis.
\end{abstract}

Keywords: Revelation. Torres Queiruga. Francisco. Image. Language of God.

Artigo submetido em 16 de maio de 2019 e aprovado em 31 de março de 2021.

* Doutor em Teologia. Professor da Faculdade de Teologia da PUC-SP. País de origem: Brasil. E-mail: nobre.jose@gmail.com 


\section{Introdução}

Entende-se que, perigosamente, a época atual apresenta traços parecidos com aquelas em que antecederam as duas últimas guerras mundiais. O grau de individualismo social que tem aparecido em posturas de líderes mundiais, implica que pensemos mais sobre a sociologia da singularidade. Entende-se que esse pensar será menos ingênuo se feito numa perspectiva cada vez maior de educação para a coletividade. Argumenta-se que a vida como um todo deve estar integrada. E por que é que, exatamente neste momento histórico teremos que enfrentar o singular? Compreende-se que não é possível entender o conjunto das disputas atuais se não apreender a trajetória de construção e reconstrução histórica. Indagase: a sociedade hoje não está preparada para pensar o individual e o seu valor no meio social, daí as intolerâncias? Quais as motivações conscientes ou não para as atrocidades do tempo presente? Como comporta o ser humano diante das esquizofrenias sociais da atualidade? São questões que preocupam a humanidade no sentido de que a responsabilidade de se refletir teologicamente nesta atual conjuntura do mundo em que se exige tecer ponderações sobre a necessidade de comunicar Deus ao mundo contemporâneo. A esse respeito entende-se que o Magistério de Francisco, aparece como uma alternativa inteligente de falar de Deus de forma suave e acolhedora. Nesse sentido é que se apresenta a riqueza do pensamento do teólogo galego, Andrés Torres Queiruga. Ele tem, em última análise, a preocupação fundamental com a tão sonhada e desafiadora realização humana.

Situado entre introdução e conclusão, o presente texto ressalta a importância de uma utilização inteligente da imagem e da linguagem adequadas para comunicar ao ser humano hodierno, o Deus misericordioso de Jesus de Nazaré. Em seguida, tecer-se-á ponderações sobre a categoria cunhada por Torres Queiruga, denominada a hermenêutica do amor, como um recomeço para a evangelização em saída, em sintonia com as opções evangelizadoras de Francisco. Entende-se que, na teologia da revelação de Torres Queiruga reside uma rica oportunidade para a protagonização e reforço dos ideais trazidos à tona pelo Vaticano II. Que foi acolhido de forma corajosa e entusiasmada, por grande parte 
da Igreja e, que com a guinada universal do Papa Francisco, passa a ter um novo fôlego. Isso é perceptível no processo de renovação e criatividade da práxis eclesiológica. O protagonismo do Magistério de Francisco evidencia a perspectiva de um projeto de Igreja em reformas. E, em sintonia com Jesus que veio de um lugar desacreditado como Nazaré, esse projeto é hoje, reinaugurado pelo Papa vindo do fim do mundo.

\section{A revelação divina e a imagem de Deus conectada com os sinais dos tempos}

Do ponto de vista de uma análise de conjuntura da contemporaneidade, não é preciso de longas análises geopolíticas para se estar de acordo de que há uma globalização da indiferença para com o próximo. É possível perceber que certas atitudes humanas atuais vêm evidenciando a falta de reações, bem como a perda do senso de responsabilidade pelos semelhantes. Isso está ratificado na degradação humana ou ecológica e surge como um sinal de alerta, reivindicando da humanidade hodierna uma predisposição dialógica, bem como uma profunda e sincera reflexão teológica (NOBRE, 2017, p. 13). Argumenta-se que a teologia da revelação do teólogo galego, Andrés Torres Queiruga (2016) aponta que "não é ousadia pensar que são milhões as deserções da fé que encontram aqui um (talvez o) motivo." (TORRES QUEIRUGA, 2010a, p. 50).

Vale ressaltar que quando, no contexto de anúncio do Concílio Vaticano II, o Papa João XXII, acenava a necessidade de uma ruptura com a cristandade, alicerçada sobre privilégios e um tempo estagnado e entrincheirado. O Pontífice estava desejando e, acima de tudo, permitindo uma aproximação entre a Igreja e o mundo, evidenciada no conceito de aggiornamento que

significa atualização, renovação, reforma mesmo. Pressupõe primeiramente um descompasso da Igreja com a sociedade envolvente, uma dificuldade, mais experimentada e sentida do que formulada, de proclamar na cultura de então a mensagem evangélica, uma convicção firme sobre o fim de uma configuração histórica do catolicismo. (MIRANDA, 2006, p. 16). 
Nesse sentido, "Para João XXII, tratava-se de uma proposta de escuta atenta à voz da Igreja, que não deve mais falar em tom de ameaça, mas em tom amoroso de mãe que não quer outra coisa senão o bem de seus filhos" (OTTAVIANI, 2017, p. 21). Nesse sentido, na urgência de reafirmar a grandeza da liberdade e da dignidade humana conectada com os sinais dos tempos, é possível entender que:

A dignidade do homem exige que possa agir de acordo com uma opção consciente e livre, isto é, movido e levado por convicção pessoal e não por força de um impulso interno cego ou debaixo de mera coerção externa. $\mathrm{O}$ homem consegue esta dignidade quando liberado de todo o cativeiro das paixões, caminhada para o seu fim pela escolha livre do bem e procura eficazmente os meios aptos com diligente aplicação. (COMPÊNDIO DO CONCÍLIO VATICANO II, 1987, n. 17).

Percebe-se que na linha de uma atenção especial aos sinais dos tempos,

com o paradigma st., João XXIII introduziu a Igreja no contexto histórico contemporâneo dos anos 1960. Interpretou esses sinais como metáfora que propõe a escuta atenta não de uma voz ameaçadora que anuncia o fim do mundo, mas da voz de Deus na realidade histórica de hoje. (SUESS, 2015, p. 896).

Ressaltados no Vaticano II, bem como de uma valorização e resgate da dignidade humana, tanto os bispos na conferência de Medellín, vendo a realidade de injustiças da América Latina, quanto o Papa Francisco olhando para o mundo, se esmeram de forma especial para que o ser humano hodierno retome essa liberdade em plena sintonia com o mistério da graça divina. Tudo isso, a fim de que a teleologia humana readquira o seu lugar para a qual foi chamada.

Nesse sentido, só para que seja traçado um itinerário de sintonia nas suas preocupações, se observar o texto de Medellín, ao tratar das prioridades da renovação catequética, por exemplo, é possível ver que:

A América Latina vive hoje um momento histórico, que a catequese não pode ignorar: o processo da transformação social, exigindo pela atual situação de necessidades e injustiça em que se encontram marginalizados grandes setores da sociedade (...). Cabe à catequese ajudar na evolução integral do homem, dando-lhe seu autêntico sentido cristão, promovendo sua motivação nos catequizados e orientando-a para que seja fiel ao Evangelho (CONSELHO EPISCOPAL LATINO-AMERICANO, 2005, n. 8.7). 
A esse respeito, se pode ver que

o documento final, aprovado pelos bispos latino-americanos reunidos em Medellín, reverbera a consciência de um continente que descobriu que os sinais dos tempos apontam para a presença de Deus entre os povos colonizados e para a continuidade da revelação de Deus nesses povos. (OTTAVIANI, 2017, p. 22).

Ampliando as atenções para uma comunhão universal, a atenção aos sinais dos tempos, faz com que Francisco possa admoestar a humanidade hodierna para que desenvolva um cuidado não somente restrito ao ser humano, mas a todos os seres vivos:

Devemos, certamente, ter a preocupação de que os outros seres vivos não sejam tratados de forma irresponsável, mas deveríamos indagar-nos sobretudo as enormes desigualdades que existem entre nós, porque continuamos a tolerar que alguns se considerem mais dignos que os outros. Deixamos de notar que alguns se arrastam numa miséria degradante, sem possibilidades reais de melhoria, enquanto outros não sabem sequer que fazer ao que têm, ostentando vaidosamente uma suposta superioridade e deixam atrás de si, um nível de desperdício tal que seria impossível generalizar sem destruir o planeta. (FRANCISCO, 2015a, p. 58).

Numa visita recente à cidade que em que se realizou a Conferência de Medellín, palco de guerras sangrentas dos cartéis do narcotráfico, o Pontífice advertiu: "É preciso fugir da tentação de vingança e da busca de interesses particulares e de curto prazo". Aconselhou Francisco no seu primeiro dia na Colômbia, durante uma recepção na Casa de Nariño, a residência oficial do Presidente e sede do Governo (Cf. SIZA, 2017).

Ainda ressaltando as palavras do Papa Francisco na Cidade de Medellín, evidencia o que Francisco relembrou:

Como cristãos, não podemos andar a exibir cartazes de 'Entrada Proibida'. Nem prender-nos a interpretações rigorosas da lei e da doutrina. Não podemos ter medo de ouvir o outro e de nos renovarmos, temos de ter a coragem de sair ao encontro e consolar quem sofre e quem precisa (SIZA, 2017).

Diante de desafios tão trabalhosos e de longo alcance, entende-se que a teologia da revelação de Torres Queiruga se apresenta, na atualidade, como uma rica alternativa para a comunicação do genuíno amor de Deus que Jesus de Nazaré 
pôs a descoberto. A imagem de um Deus amoroso, aliado do ser humano, que cria em vista da salvação e que quer pura e tão somente a realização desse ser humano, uma vez que foi criado por puro amor. Ela aponta que a crise moderna consiste numa grande oportunidade para redescobrir a experiência cristã original.

A crise moderna constitui uma magnífica ocasião para redescobrir, em toda a sua frescura e vigor, a experiência cristã original, libertando-a de excrescências que a defrontam e obscurecem. Desse modo, pode então confrontar-se com a nova situação cultural, em concreto, com a autonomia do mundo, e abrir, assim, a possibilidade de um encontro verdadeiramente renovado. O passado, e a "tradição" não desaparece, pois continua a existir como lição perene, em cuja wirkungsgeschichte [história dos efeitos] vivemos e que preserva em si a experiência originária junto com lições que não devemos esquecer. Mas o corte cultural mostra que não podemos tratar de uma continuidade ingênua, mas que deve incluir também rupturas e críticas mediante a confrontação direta com a experiência das origens. (TORRES QUEIRUGA, 2005, p. 53).

Entende-se que o fragmento acima ilumina com muita clareza o processo de construção de um itinerário que a reflexão teológica deve seguir a fim de responder aos desafios do tempo presente. Essas referidas rupturas e críticas recaem também sobre a imagem de um Deus que é misericordioso e que convida a humanidade a retomar as experiências das origens do verdadeiro amor de Deus. De modo que "onde houver cristãos - qualquer pessoa deve poder encontrar um oásis de misericórdia." (FRANCISCO, 2015b, p. 15). Para essa grande e sublime tarefa de comunicar com eficiência a essência da mensagem revelada, de forma que ela seja assimilável e vivenciável na cultura hodierna, entende-se que a teologia da revelação de Torres Queiruga se torna basicamente indispensável. Ou seja, estando consciente de que todo processo de evangelização crítico e consciente tem em mente que é cultivando a riqueza originária e os aprendizados da tradição em sintonia com os sinais dos tempos é que, os seres humanos serão capazes de proporcionar um renovado e verdadeiro encontro entre tradição e modernidade, renovando desse modo as culturas. E, consequentemente, a vida digna, especialmente aos seres empobrecidos. Só assim será possível entender que a reflexão teológica será capaz de corresponder aos anseios da atual conjuntura sociocultural, iluminando as questões atuais à luz da revelação de Deus. Segundo o teólogo galego, faz-se necessário, entretanto, ter sempre em mente a verdadeira 
imagem de Deus que na Cruz de Cristo foi desvelada. Sendo assim, é imprescindível olhar nas duas direções: vertical e horizontal.

Entende-se que, para uma compreensão atualizada da revelação divina, como uma teoria da religião, se faz necessária uma verdadeira vivência dos ideais de Cristo. Sendo assim, a teologia de Torres Queiruga aparece como uma alternativa inteligível, um ponto de convergência e de interlocução. Entre tantas outras criatividades, por exemplo, ela ressalta que se faz necessário levar em conta, de forma rica e progressiva, o diálogo e o encontro com as religiões, tarefa que Francisco tem feito exemplarmente. Para tanto, é preciso levar em consideração a imagem e a linguagem de Deus que devem estar em plena sintonia com aquelas reveladas no Nazareno. Esclarece-se, outrossim, que apenas ser faz menção a essas temáticas (imagem/linguagem), sem que elas sejam diretamente uma panaceia para a resolução de todos os desafios da evangelização hoje.

Sabe-se que cultivar uma imagem genuína do Deus amoroso ao longo de uma história bimilenar, no meio de uma realidade cultural secular e globalizada ${ }^{1} \mathrm{e}$ com dimensões planetárias, nem sempre constitui tarefa fácil. Entende-se que muitos "penduricalhos" são jogados em cima da imagem divina, cuja responsabilidade de fazer eclodir a imagem originária do Deus de Jesus Cristo, recai sobre a teologia da revelação. Sabe-se que, tendo em vista a necessidade pastoral de oferecer ao mundo de hoje uma genuína imagem de Deus - revelada plenamente em Jesus Cristo. "Ele é a imagem do Deus invisível, o Primogênito de toda a criatura, [...], pois nele aprouve a Deus fazer habitar toda a Plenitude” (Cl 1,15.19), Andrés Torres Queiruga tem dispensado muito de suas energias e atenção.

É possível perceber essa sua preocupação, de maneira muito sutil, na simples observação dos títulos de suas próprias obras. Só para citar alguns, o modo como ele as "batiza", revela claramente a imagem de Deus que ele advoga: Um Deus para hoje (2011); Alguien asi es el Dios em quien yo creo (2013); Creio em

\footnotetext{
1 Entretanto, já é possível entender que, com as posturas de fechamentos e posições conservadoras de muitos líderes mundiais, a realidade globalizante já apresenta sinais de nova configuração das relações culturais. O brexit e a polêmica ereção do muro no México, por exemplo, já evidenciam esses sinais.
} 
Deus Pai: o Deus de Jesus Cristo como afirmação plena do humano (1993) e Repensar a revelação: a revelação divina na realização humana (2010). São títulos que emitem não somente uma imagem de Deus, como também o resultado da genuína percepção dessa imagem como condição para a realização humana, a começar por este último. Percebe-se uma imagem de Deus atualizada no hoje da história. Imagem de confiança, de esperança, de realização e tantos outros adjetivos positivos que o teólogo galego quer evidenciar para a humanidade hoje e que faz interlocução com as teologias latinoamericanas: indígena, negra, feminista, da libertação, bem como do Magistério de Francisco. Acerca disso veja:

"Um Deus para hoje". O título soa necessariamente pretensioso. Mas deveras só deseja apontar a necessidade de repensar continuamente nossas imagens de Deus e fazê-lo, portanto, também para hoje. Estamos convictos de que qualquer tentativa de força acabará naufragando em seu empenho de remeter-nos a Mistério tão grande. E, não obstante, temos a esperança secreta de fazê-lo de forma um pouco menos inadequada, sob algum aspecto, pelo menos. Em todo caso, é claro que compete a cada tempo apostar em seu ensaio de dar resposta minimamente significativa a suas interrogações precisas: só assim suscitará atitudes e promoverá práxis que lhe ajudem nas urgências de seu respectivo momento. (TORRES QUEIRUGA, 2011, p. 5).

Não é sem intenção premeditada que se insere esse fragmento neste local. Foi exatamente para ressaltar a imagem de Deus que, se apresenta como um pano de fundo das intenções do Magistério de Francisco que é o que com todo o esmero, o teólogo galego quer apontar para a cultura hodierna. Nesse fragmento, ele deixa evidente a sua preocupação pastoral, como ele próprio diz, que ajuda "nas urgências de seu respectivo momento". É uma maneira mistagógica de falar, que reivindica as responsabilidades dos seres humanos criados por amor de comunicar a verdadeira imagem de Deus aos seus semelhantes ensimesmados no "ringue" da vida.

Assim procedendo, incumbir-se-á o ser humano, no tempo presente, a fim de continuar a repensar a imagem de Deus que melhor se ajuste à compreensão da criatura hodierna. Basta uma atenção mais apurada às próprias palavras do autor para cair na conta de suas pretensões. Com profunda lucidez, ele deixa claramente a descoberto que é necessário e urgente repensar a imagem de Deus para hoje. 
Inclusive os verbos repensar e recuperar estão presentes de maneira intencional como títulos de suas obras, exortando o leitor sobre a necessidade de continuar nesse processo de repensar continuamente a imagem de Deus. Uma imagem que seja capaz de se comunicar com a sensibilidade moderna do ser humano. Ressalta que Deus é presença sempre atual a promover, sustentar e habitar a sua criatura. Pondera que, infelizmente, esse tipo de pensamento tem sido objetivante na sociedade secular atual. Isso vai deformando a genuína experiência bíblica de um Deus em profunda comunhão com o ser humano criado por puro amor. A esse respeito, assim se expressa o teólogo galego:

A denúncia dessa deformação, que Hegel intuiu como máxima urgência nos primórdios da modernidade, pode ajudar a repensar a revelação, de sorte que nos permita assimilar hoje alguns dos valores fundamentais da sensibilidade pós-moderna, apoiando-os no que têm de mais positivo, sem por isso sucumbir aos demônios que ameaçam deitar fora suas conquistas. Tendo em conta as exposições anteriores, atenderei a aqueles mais imediatamente relacionados com o tema atual, sobretudo como se mostram a partir da preocupação pós-moderna. (TORRES QUEIRUGA, 2003, p. 127).

Num mesmo fragmento, encontram-se duas vezes a sua referência à pósmodernidade. Logo, não o faz por equívoco. Enfim, o que mais interessa neste ponto é a exortação do professor de Compostela sobre a responsabilidade de cada tempo se dedicar à tarefa de repensar sobre a imagem de Deus que seja inteligível e crível pelas pessoas de todos os tempos e lugares. Em tempos de Francisco, é possível perceber essa plena sintonia de propósito de estabelecer uma comunicação da fé revelada como uma eficiente teoria da religião de modo que esteja em sintonia com os desafios dos tempos atuais. Pois, sabe-se que é desejo de Deus estabelecer comunicação com o ser humano criado por amor e, para isso, utiliza-se de diversos modos. "Muitas vezes e de modos diversos falou Deus, outrora, aos Pais pelos profetas; agora, nestes tempos, que são os últimos, falou-nos por meio do seu Filho, a quem constituiu herdeiro de todas as coisas, e pelo qual fez os séculos” (Hb 1,1-2). Sendo assim, entende-se que nas pegadas de Francisco, a teologia da revelação de Torres Queiruga, como uma teoria religiosa eficaz e ciente da evolução dos tempos, reivindica esse repensar contínuo da revelação, a fim de garantir a realização humana no dinamismo da história. Mas qual é realmente a imagem ou as imagens 
de Deus que Torres Queiruga e Francisco tem em comum com a pobreza evangélica? Só para citar um exemplo, quanto ao Papa Francisco, - sem mencionar os seus gestos e pregações -, a começar pela Alegria do Evangelho, ressalta-se que ele evidencia a imagem de um Deus alegre. "Veio o Filho do Homem, que come e bebe, e dizem: 'Eis aí um glutão e beberrão, amigo de publicanos e pecadores"” (Mt $\left.11,19^{\mathrm{a}}\right)$. Essa é uma das principais que vem à tona. A esse respeito ele ressalta a necessidade de recuperar a alegria cristã. E com o professor galego não é diferente:

Falar de alegria de Deus pode tomar-se como genitivo subjetivo: alude então a alegria que Deus vive em si mesmo e em suas criaturas, no mistério de sua felicidade infinita. Pode significar também genitivo objetivo: o tema, mais modesto, da alegria que o ser humano sente diante de Deus e ante Deus. A esta vou referir diretamente, embora o primeiro aspecto permaneça como transfundo fascinante e como fundamento radical (TORRES QUEIRUGA, 2013, p. 18).

Fundamentando-se em Nicolau de Cousa e em Spinoza ${ }^{2}$, o professor de Compostela ressalta que a alegria infinita de Deus em si mesma sustenta a alegria do ser humano de fé. Dito de outra forma, quando o crente for capaz de perceber a Deus e entrar em sintonia com Ele, ele será plenamente capaz de se alegrar no Senhor. Em Deus não há solidão, no sentido de tristeza castrante. "Alegrai-vos sempre no Senhor! Repito: alegrai-vos!” (Cf. Fl 4,4). Argumenta-se diante disso que a necessidade humana de encontrar sentido para a vida está à mercê da experiência de Transcendência para a sua plena realização. A experiência mística como ponto culminante entre a vida e a fé está a dizer ao crente que a sua alegria acaba por coincidir com a alegria divina que é capaz de ressignificar a vida.

[...] constatamos que vivemos num momento onde a cultura passa por profundas mutações, em que o fato religioso enfrenta diversas posturas, desde a indiferença até o ateísmo. Nesta situação, vimos que a experiência é o caminho por excelência da comunicação e transmissão de valores a um ser humano desencantado e ao mesmo tempo sedento de Transcendência e Espírito que dê sentido a sua vida. Procuramos então cercar cuidadosamente o conceito de experiência e, depois, de aplicá-lo teologicamente à religião. Esta análise nos conduziu à experiência mística, que todos os pensadores, estudiosos e crentes consideram como ponto culminante da vida de fé. (BINGEMER, 2013, p. 433).

${ }^{2}$ A esse respeito conferir (TORRES QUEIRUGA, 2013, p. 19). 
Entende-se que essa sede de Transcendência acontece com quem se encontra naquilo que se chama de estar em estado de graça. Mediante esse estado, a face transfigurada de Deus reluz na sua criatura. Especialmente nos tempos hodiernos marcados pela cultura do apego excessivo, bem como do ódio e pelas atrocidades de todos os tipos, a necessidade de retomar os ideais trazidos pela teologia da revelação de Torres Queiruga e do Papa Francisco retomam com força, quando toda a criatura é solicitada a fazer um distanciamento das coisas criadas, a fim de ser capaz de ver Deus nelas. "Não podemos ver as coisas em profundidade enquanto as afagamos, a elas nos agarrando. Quando delas abrimos mão, começamos a apreciá-las como são em realidade. Só então podemos começar a ver Deus nelas." (MERTON, 2014, p. 17). Esse ver Deus nas coisas criadas é uma atitude que Torres Queiruga aponta como maneira de o crente se alegrar no Senhor, por se saber acompanhado pela riqueza do seu amor. A partir desse modo de ver, esse novo olhar para perceber Deus, está em plena sintonia com os ensinamentos do Magistério de Francisco. Nesse sentido, entende-se que o ser humano criado por amor é desafiado a fugir da tristeza e do isolamento. Convida o homem de fé a se afastar de toda retórica minimalista, desconstrutiva e totalitária cujos tempos hodiernos valorizam. A esse respeito adverte que quem pensa ter chegado à finitude irreversível, ser faz necessário reacender a esperança de uma plenitude futura:

Contudo, a consciência cristã nos diz que nem por isso temos de nos tornar prisioneiros da pura finitude. Uma vez que Deus habita tudo, que é o 'Todo no fragmento' [Balthasar], o concreto não se detém na tristeza do coto isolado, mas pode ser vivido como membro incorporado em uma realidade mais ampla e definitiva, como antecipação esperançosa: 'sinete e penhor' (2Cor 1,22) da plenitude futura. (TORRES QUEIRUGA, 2003, p. 128).

Em suma, quando o teólogo galego pondera sobre a importância da alegria cristã, não está se referindo a um sentimentalismo imediato e piegas. Mas sim ele fala de uma percepção forte do Transcendente, que, apesar dos sinais de morte, não se deixa abater, pois percebe que, nesse meio, a presença marcante de Deus se faz forte, suscitando o sorriso e a felicidade. Especialmente aí, ele está "realizando a paz pelo sangue da sua cruz." ( $\mathrm{Cl}$ 1,20b). Outras imagens fortes que o teólogo 
galego ressalta e que estão em plena interlocução com Francisco, são as do Deus da compaixão, da coragem e da esperança. Ressaltando a compaixão solidária do amor de Deus por sua criatura, é possível entender que, apesar de todas as desesperanças, Deus oferece a coragem e a esperança. Assim, a pessoa humana sabendo-se empoderada e emancipada por Deus, será capaz de transformar, democraticamente a "Grande Sociedade" na "Grande Comunidade" (NOBRE, J. A; MENDONÇA, S, 2016, p. 28). Desse modo, possibilita a coragem necessária para que todos se mantenham de pé sobre a face da terra.

É uma maneira de se estender a vocação de salvação universal oferecida a todos. De modo que, na liberdade do Espírito, faz-se necessário que todos, na contemporaneidade, tenham acesso à verdadeira imagem do Deus amor. E, a partir de então, no uso de sua consciência, acolhê-Lo ou rechaçá-Lo. Crê-se, assim, que, dificilmente a segunda opção terá êxito, pois, sabe-se ser impossível encontrar-se com a misericórdia de Deus e permanecer indiferente. "Tu me seduziste, Iahweh, e eu me deixei seduzir; tu te tornaste forte demais para mim, tu me dominaste" (Jr 20,7). O professor de Compostela aponta que uma vez seduzido pelo amor desconcertante de Deus, a pessoa humana terá sempre a coragem de lutar e, mesmo que seja derrotada, saberá se inspirar nos exemplos de Jó e de Jesus de Nazaré ao entender que:

Na carne traspassada pela cruz, verá o Deus da ressurreição. Só por ter-se deixado corrigir-se a tempo, a falsa imagem de uma onipotência arbitrária, puderam alguns crentes pensar que depois de Auschwitz era impossível orar. A partir do Deus vivo e verdadeiro, compreendemos o contrário: só orando é possível esperar, apesar de Auschwitz, porque só a fé em Deus - e nenhum outro sistema ou ideologia sobre a terra - é capaz de manter viva a esperança das vítimas dentro do terror brutal da história. (TORRES QUEIRUGA, 2011, p. 23).

Assim, pode-se observar que a experiência de revelação divina, longe de conservar a imagem de um Deus indiferente, vem enfatizar que ela brota do interior humano e

[...] se realiza através do lento, duro e sinuoso trabalho da subjetividade humana. Não é algo de "vem de fora", mas algo que "sai de dentro": constitui, justamente em aperceber-se da Presença que nos constitui, nos habita e, desde sempre, procura se manifestar a nós. (TORRES QUEIRUGA, 2003, 129). 
O Vaticano II, ao refletir sobre a revelação como tal, já acena claramente sobre a realidade dessa Presença criadora do universo, de forma que as obras realizadas por Deus na história da salvação manifestam e corroboram os ensinamentos e as realidades significadas pela Palavra (COMPÊNDIO DO CONCÍLIO VATICANO II, 1987, nn. 2-3). Cabe agora à teologia da revelação renovar a esperança e recriar a experiência cristã a partir de sua novidade original.

Só a esperança, como virtude teologal, permite-nos avançar sem medo até as raízes desse momento crucial no qual se encontra o cristianismo. Momento que só pode ser comparado com o que foi aquele momento decisivo no qual a fé cristã teve que "passar" - êxodo e páscoa verdadeiros - do judaísmo para o helenismo. Porque não se trata de retoques nem de reformas. O que está em jogo é uma verdadeira re-criação da figura histórica do cristianismo. $\mathrm{E}$ a oportunidade única de recriar a experiência cristã a partir da sua novidade original. (PALÁCIO, 2004, p. 195).

Para tanto, se faz necessário valer-se de uma mistagogia clara e direta para o fiel continuar a transmissão da verdade da revelação numa linguagem sempre nova, a linguagem de Deus todo poderoso no amor. "Pois a Igreja experimenta em nossos dias grande dificuldade em transmitir a fé para as novas gerações, sinal de alarme que exige um exame sério dos canais tradicionais dessa transmissão. " (MIRANDA, 2013, p. 213).

Sabe-se desse modo, que o contexto sociocultural, as condições de vida dos ouvintes são outros, de tal modo que uma mensagem de fé somente será levada em conta pelos seus fiéis se essa mensagem considerar a realidade das suas vidas nas circunstâncias em que vivem. Diante da constatação de desafios de comunicação da novidade da revelação, valendo-se de uma linguagem pautada no Evangelho, entende-se, que em plena interlocução com as inspirações do Magistério de Francisco, Torres Queiruga recorre à memória para dizer que as atitudes de fechamento não podem ser esquecidas para jamais serem repetidas. Não é por acaso que ele admoesta que "um pensamento objetivista e abstrato se converteu em jaula de ferro para o dinamismo da fé, impermeabilizando-o em grande medida para a nova sensibilidade cultural. " (TORRES QUEIRUGA, 2013, p. 169). Daí o grande desafio de comunicar a revelação na justa linguagem de um Deus para hoje. 


\section{A revelação divina e a linguagem de Deus}

Como se sabe, a revelação divina não consiste numa linguagem hermética, senão, certamente, seria algo inútil para a sua assimilação. Contudo, ela deve transformar a linguagem do cotidiano de modo que, por meio dessa linguagem acessível a todos, o Mistério possa aparecer, se desvelar. Em sintonia com as exigências dos tempos hodiernos, percebe-se o esforço do atual Pontífice para que todos adotem essa chave de evangelização. Entende-se que é mediante uma linguagem compreensível que se faz a proclamação da fé chegar ao ser humano concreto. "De fato, a proclamação da fé jamais se dirige ao ser humano em geral, pois este nunca existiu, porém sempre a homens e mulheres vivendo numa época histórica e numa sociedade concreta. ” (MIRANDA, 2013, p. 214). A questão da linguagem de Deus, como assim aqui se refere, entendendo essa como linguagem religiosa utilizada na transmissão da fé revelada, é considerada pelo teólogo galego com algo difícil, mas essencial.

Não é questão de carregar ainda mais a consideração com novas análises deste tema difícil de abordar, mas que espero, está suficientemente claro e sugestivo. Contudo, faltaria algo essencial à abordagem, se não se dissesse ao menos alguma coisa acerca da linguagem religiosa. Nela se revela necessariamente a índole e a experiência reveladora que a sustenta e, por sua vez, constitui o ponto de sua decisiva iluminação. (TORRES QUEIRUGA, 2010b, p. 205).

Esse ponto de decisiva iluminação da revelação de Deus, mediante a índole e a experiência reveladora da linguagem religiosa, que põe a descoberto a plenitude do Mistério, nunca é absolutamente comunicável no sentido em que o próprio termo parece transparecer. Naturalmente, a comunicação da fé revelada numa nova cultura, ao longo da história, sempre enfrentou obstáculos, críticas e negações. "Isso exigia uma verdadeira revolução, que ameaçava a própria continuidade da fé." (TORRES QUEIRUGA, 2016a, p. 27). É preciso levar em conta conscientemente que a linguagem de Deus sempre será "prejudicada", uma vez que está sujeita à limitação humana. Entretanto, as limitações e dificuldades nunca devem se sobrepor ao querer divino que é a realização última do ser humano. Realização que se dá com Deus, que sempre vem em favor do humano. 
A certeza da fé e a inquietude da espera farão parte da luta do teólogo, uma luta que ele deverá travar com sua experiência de Deus, pois o fazer teológico se faz com aquilo que se acredita, com aquilo que dá sentido e razão no existir; o fazer teológico se faz na entrega e, principalmente, no serviço. Discursar sobre Deus, teologicamente, é falar da realização última do ser humano com Deus, do encontro escatológico, da plenificação humana e da concreta ação de Deus que vem em nosso favor (KUZMA, 2016, s/p).

Desse ponto de vista, o fragmento acima traduz muito fielmente o espírito do que advogam os ideais de Francisco e de Torres Queiruga ao longo de sua obra. Percebe-se aí, que é possível fazer uma profunda associação entre revelação divina e realização humana. Ressalta-se que, o não dito de tudo isso, é que já foram captados os sopros do Espírito Santo para os tempos hodiernos, contudo as ondas ultraconservadoras de todos os tempos e lugares sempre estão a soprar no sentido contrário. Argumenta-se que a realização humana é sempre atrelada à noção de um Deus que vem em favor dos seus filhos, especialmente no momento do sofrimento. "Justamente porque sente a mordida do sofrimento, o doente sabe que Deus se põe prioritariamente a seu lado; justamente porque é marginalizado e explorado pelos homens, o oprimido escuta que Deus se põe ao seu lado." (TORRES QUEIRUGA, 2011, p. 23). Em outras palavras, a teologia da revelação do teólogo galego em interlocução com o Magistério de Francisco enfatiza a importância de abertura à linguagem de Deus, pois "trata-se de uma transformação da linguagem mediante a linguagem, com a ajuda de estratégias adequadas, que tornam patente sua radical e infinita abertura. " (TORRES QUEIRUGA, 2010b, p. 205).

Não obstante a tessitura do Mistério revelado, escapar à capacidade humana de comunicação direta da mensagem revelada na própria linguagem religiosa, é criativo observar a capacidade humana de se comunicar na linguagem do Mistério. Visualiza-se isso no trecho a seguir. Trata-se de uma das formas poéticas de se expressar, quando ressalta que a fé sempre terá o todo do Mistério revelado no fragmento da linguagem. "Embora a fé do cristão se dirija à plenitude do mistério de Deus, inacessível ao conhecimento humano, ela sempre terá o todo no fragmento da compreensão, da linguagem e da expressão humana condicionadas e limitadas." (MIRANDA, 2013, p. 214). Entende-se que somente uma mente espiritualizada perceberá, como que num prisma de contemplação, a 
beleza do Mistério revelado onde o todo está implicado no menor fragmento. As Sagradas Escrituras, como fonte que é por excelência de revelação divina, reluzem a totalidade do Mistério no todo do cotidiano, onde Deus se mostra e evidencia os seus apelos na vida em que vivida.

A Bíblia faz saber quem é Deus, como ele se revela. [...] Faz saber onde podemos encontrar Deus e os seus apelos na vida que vivemos [...]. Ninguém pode dizer uma coisa dessas por si mesmo, mas somente quando atinge diretamente da fonte. (MESTERS, s/d, p. 9-11).

A seriedade, a responsabilidade e as consequências do uso da linguagem para comunicar a mensagem revelada no transcorrer da teologia da revelação estão sempre correlacionadas com as buscas límpidas diretamente da fonte do Mistério revelado. Sabe-se pela história da revelação que, por força de uma ineficiência e coragem de abertura a uma linguagem que prezasse pelo entendimento e distinção dos objetos em jogo, de mútua ajuda entre ciência e fé, os avanços desejados ficam por aterrissarem na prática: no caso o dinamismo da fé e as conquistas da ciência. A teologia da revelação de Torres Queiruga, com um ponto de convergência em Francisco, enfatiza a necessidade desse avanço na comunicação do Misterioso amor de Deus na contemporaneidade.

\begin{abstract}
Existe algo de fatal no fato de que, enquanto o mundo secular se desencadeia, sobretudo a partir de Descartes, na formação de uma nova filosofia, e se forja uma consciência radicalmente histórica, no mundo religioso [...]. As grandes conquistas do Espírito moderno, a ciência, a história, a epistemologia do sujeito, a crítica social, a psicologia profunda, a consciência histórico-evolutiva [...] ficaram indefectivelmente em uma postura marginal, quando não francamente hostil, perante o transcorrer da teologia. (TORRES QUEIRUGA, 2013, p. 169).
\end{abstract}

Entende-se que a linguagem deve ser viva e, enquanto comunicadora da revelação e da força do Mistério de Deus, deve conter o "som” e a "voz" desse Mistério, sem medo nem retrações. Na experiência cristã, muitas vezes ou por medo ou ignorância das opções de fechamento ao Mistério, alguns seres humanos acabaram por buscar refúgios em atitudes imaginárias, com receio de assumir o presente a fim de transformá-lo. 
É a tentação de todos aqueles que, ontem como hoje, são incapazes de suportar o lado sombrio da história do cristianismo que se reflete no rosto da Igreja; essa Igreja santa e pecadora, que os Santos Padres não hesitavam em denominar, sem embaraço, casta meretriz. Mas para os cátaros de todas as épocas, a opacidade da vida da Igreja é insuportável. Por isso, em nome de um cristianismo "ideal", refugiam-se num futuro imaginário que os exime de carregar o presente nos seus ombros, para encarregar-se dele e assim transformá-lo. (PALÁCIO, 2004, p. 194).

Cabe à sutileza do mistério contido na linguagem da revelação divina a difícil tarefa de aproximar as pessoas e estabelecer comunicações das mais variadas naturezas. Argumenta-se que a linguagem teológica sempre transita exatamente no meandro das limitações humanas de todos os tempos e lugares. E é justamente nesse meio que ela está desafiada a comunicar as experiências de desvelamento.

Há muitas linguagens capazes de levar a 'semente da Palavra' pelo mundo afora. Atualmente, a Igreja vive em meio a forte mudança cultural [...]. Paradoxalmente a 'globalização' não produz necessariamente a aproximação mútua das pessoas. (KONINGS, 2011. p. 53).

Como a fé cristã não deixa dúvidas de que o Espírito Santo de Deus segue vivo na Igreja, sabe-se que, felizmente, nem todos os crentes e teólogos se deixam resignar, mas, tocados pela doçura do amor de Deus, revelado em Jesus Cristo, seguem na trilha do Mistério que dá vida. Assim é o que faz perceber a obra do teólogo galego.

Digamo-lo com um exemplo concreto: a criação do homem no capítulo 2 do Gênese segue conservando todo o seu valor religioso e toda a sua força existencial para uma leitura que trate de ver aí a relação única, íntima e amorosa de Deus com o homem e com a mulher, a diferença da que mantém com as demais criaturas. Porém para vê-lo assim, é indispensável traspassar a letra das expressões. Pelo contrário, se se persiste em ler nesses textos, de evidente caráter mítico, uma explicação científica do funcionamento real do processo evolutivo da vida, converte-se tudo em puro disparate. De feito, sabemos muito bem que durante quase um século neste caso concreto a fidelidade à letra converteu-se uma terrível fábrica de ateísmo, tornando verdade a advertência paulina de que 'a letra mata, mas que o Espírito dá vida (2 Cor 3,6). (TORRES QUEIRUGA, 2016b, p. 9).

Por um lado, realmente há aqueles que, normalmente, não suportam o peso das transformações que as experiências de desvelamento provocam. Preferem ficar “presos” à letra da lei a embarcar no voo libertário e dinâmico do Espírito. Como 
Deus não está pobre com o que Ele já doou para a humanidade, assim como também o Espírito Santo não se deixa aprisionar e nem ser privatizado, além de Ele ser cativante, sempre será acolhido por algumas criaturas receptivas que, por isso mesmo, são abençoadas e inspiradoras.

Por outro lado, movidas pela fé, essas criaturas, no exercício do fazer teológico, deixam-se tocar pela graça transbordante do Transcendente. Alimentadas por essa graça, são capazes de enxergar a vida de forma transponível. Entende-se que nessa dinâmica estão em sintonia os ensinamentos do Magistério de Francisco e a teologia da revelação de Torres Queiruga. Isso está posto nos movimentos espiralados e ascéticos, na inquietude da esperança e no contato com o mundo que sofre. Nesses espaços privilegiados da revelação divina, enfrentam o presente de forma corajosa e motivadora, mediante a fé no Deus revelado em Jesus como amor desconcertante. Argumenta-se que a certeza da fé, mesmo em meio às tribulações, produz a perseverança e desencadeia virtudes. Essas são capazes de provocar a esperança que não decepciona ( $R m$ 5,3-5), fazendo renascer assim, muitas perspectivas inovadoras.

É no contato com o mundo, principalmente com o mundo que sofre, que o teólogo e a teóloga terão a experiência de Deus. É quando o amor que é filia transformar-se-á em ágape, é quando o Espírito nutrirá e nos encherá de vida, é quando sentiremos o calor da vida cristã que é capaz de transformar e a força da ressurreição nos acalentará e nos fará renascer (KUZMA, 2016, s/p.).

Por fim, entende-se que o uso dessa linguagem mística, simbólica e positiva da vida conserva toda uma riqueza histórica das diferentes formas de percepção da presença amorosa de Deus, mediante a qual Ele se revela. Nesse sentido, percebese que o esforço e a pressa nas "reformas de Francisco que se encontram em curso tocam em um sistema complexo e envolvem diferentes aspectos. " (PASSOS, 2017, p. 353). Essa diversidade de aspectos aponta para esse caminho desafiador que tem em sua frente o tempo todo, a teoria da revelação divina a todo tempo como desdobramentos para evidenciar a misericórdia de Deus. Considera-se pois, importante ter sempre em mente que a teoria da revelação divina, enquanto categoria em reforma contínua, acumula a sabedoria anterior, de maneira que 
carrega em sua linguagem e, em si mesma, uma história englobadora, com caráter de totalidade. E isso ela traz como base fundamental para a comunicação da revelação de Deus ao ser humano hodierno, tendo a sensibilidade de não deixar nada de fora do amor de Deus:

Com o que se viu anteriormente fica expresso o fundamental da revelação: essa história englobadora na qual o ser humano se vai descobrindo e realizando em sua intimidade, enquanto fundado, determinado e entregue a si mesmo pelo Deus que a ele se comunica. Isso deve permanecer como base irrenunciável que alimenta toda a reflexão (TORRES QUEIRUGA, 2010b, p. 199).

Entende-se, assim que o aprendizado com a história da revelação divina e a sua linguagem ao longo do tempo, mostra que o aberto intercâmbio de ideias nas sensibilidades das bases eclesiais, como real práxis teórica dos teólogos, faz-se necessário e urgente. Nesse sentido, trabalhar com disponibilidade para a superação de todo tipo de etnocentrismo constitui em um passo imprescindível para a comunicação de Deus com uma efetiva socialização da linguagem de revelação. Em se tratando de socializar as experiências de revelação, a obra de Torres Queiruga aponta que isso será mais facilmente aplicável, mediante uma linguagem comum a todos, em prol da genuína realização humana.

O homem que passa pela experiência de desvelamento sabe o verdadeiro caminho pelo qual a linguagem de revelação toma lugar no mundo. Por isso, entende-se, que o seu fundamento e realização estão em Deus. Assim, o ser humano se deixa surpreender por esse Deus sempre presente e surpreendente. Compreende-se, assim, que as reservas divinas jamais se esgotam. Logo, estão sempre abertas ao presente histórico de Deus com o homem, a fim de comunicá-lo na linguagem de Deus.

Compreende por fim, que Deus quer ser visto por meio da felicidade e realização humana. Entende-se que o desafio para o ser humano e consequências em sua existência consiste em não deixar de realizar a sua teleologia, jamais 
abdicar de testemunhar o amor de Deus perante o ateísmo3 no mundo de hoje. Daí a necessidade de comunicar com eficiência a genuína revelação de Deus acompanhando o avanço intrépido das mudanças, na encarnação da fé, torna-se cada vez mais visível a olho nu.

\section{A hermenêutica do amor como aplicação prática da maiêutica histórica}

A teologia da revelação de Torres Queiruga tem a sua aterrissagem naquilo que se chama de hermenêutica do amor. Toda a inércia de que o campo eclesial padece hoje.

Podemos prever (o que já vem acontecendo) que a situação atual provocará uma diminuição da população de cristãos batizados e desprovidos de vivência e prática religiosa séria, que viviam tranquilamente numa sociedade de cristandade. Não lhes bastará mais uma tintura superficial de religião e práticas devocionais festivas, quando não interesseiras. (MIRANDA, 2009 p. 132).

Pode-se atribuir a uma mentalidade presa à concepção clássica de revelação. Essa apregoa um Deus indiferente, punitivo e distante da vida. Sabe-se que essa mentalidade não atrai o ser humano para um engajamento pastoral e uma vivência madura da fé. Argumenta-se que se o homem conseguir captar um Deus que se interessa pelos seus atos, certamente terá engajamento eclesial efetivo. O resultado certamente será um ato dinâmico, pessoal e coletivo na construção do Reino.

Entende-se, pois, que é nesse ato dinâmico, sempre ativo e presente cuja inspiração do Pontífice reside. Concomitantemente aos ensinamentos inspirados também na teologia da revelação de Torres Queiruga circunscreve-se o desafio da atualidade a tornar o fiel cristão em genuínos promotores, motivadores e sustentadores da existência mesma do ser humano criado-criador e colaborador da dinamicidade do Reino.

\footnotetext{
3 A este respeito, a Gaudium et Spes n. 19 admoesta: "neste gênese do ateísmo, grande parte pode ter os crentes, enquanto, negligenciando a educação da fé, ou por uma exposição falaz da doutrina, ou por faltas na sua vida religiosa, moral e social, se poderia dizer deles que mais escondem que manifestam a face genuína de Deus e da religião".
} 
Não basta afirmar o intrinsecismo da revelação, é preciso chegar à sua raiz última: criação por amor. Como creatiio continua, é presença sustentadora e promotora, sempre ativa: não os criou in illo tempore, abandonando-os deisticamente na terra, enquanto ele permanece no céu. Não sendo movido por necessidade ou carência, Deus cria unicamente por amor: cria homens e mulheres, como filhos e filhas, não 'para a própria glória ou serviço', mas para que alcancem a máxima realização possível. Por isso, seu interesse decisivo é manifestar-se a eles e ajudá-los, revelarse a eles e salvá-los. Existe algum pai ou mãe decente que não procure o mesmo para os seus filhos? Poderia esquecê-los uma mãe humana, mas Deus jamais (Is 49,95). E sendo o seu 'um amor maior do que tudo que se possa pensar', se há limites neste processo, não pode vir nem de sua reserva - ou, contra certas modas, de seu 'silêncio'! - nem de sua mesquinhez. A revelação perde assim seu caráter de processo isolado, milagroso ou arbitrário. [...]. E, pelo lado humano, como um 'cair na conta' desse Deus que estava a falar-nos na realidade, na história e na vida. [...]. Por isso, jamais existiu ninguém, homem ou mulher, indivíduo, sociedade ou cultura, que nasçam desamparados de seu amor incondicional e a quem não queira manifestar-se o mais possível (TORRES QUEIRUGA, 2007, p. 111).

É possível perceber na intensidade dessas palavras que a noção de revelação de Deus, abordada na literatura queiruguiana, ela enleva a criatura humana a um novo patamar de consciência e de autorrealização. Julga-se impossível a pessoa permanecer na inércia, quando captar o estonteante e universal amor de Deus. Portanto, "em função de ser o amor de Deus o núcleo do centro do pensamento de A. T. Queiruga é que se faz necessário falar de uma 'hermenêutica do amor'. Esta tem a função prática de iluminar a maiêutica histórica.” (ROCHA, 2010, p. 268).

Como deve ser todo amor, Torres Queiruga faz ver que Deus é amor e todas as suas ações manifestam o seu verdadeiro Ser. A sua percepção provoca a conversão humana. A Palavra Sagrada, instruída pela nova concepção de revelação, desvela na história a ação de um Deus amoroso. Possibilita a realização humana a partir de sua consciência do local onde o homem está situado. Quando se fala de realização humana, refere-se a uma vida plena de sentido. É quando o ser humano toma conhecimento de que a sua vida não deve passar em brancas nuvens. Sabe que a sua constituição humana só é plena, necessariamente, por originar-se apartir-de-Deus-no-mundo. Isto é, o ser humano se entende protegido e acompanhado em tempo real pelo Criador de todas as coisas. A partir do Magistério de Francisco, e da teologia da revelação de Torres Queiruga o ser humano se dar conta cada vez mais de que Deus se importa com a sua criatura. 
Esse entendimento é tão significativo para o ser iniciado no processo revelador, despertando a pessoa humana a uma sincera conversão. Não uma conversão qualquer como um sentimento de negatividade, mas de preenchimento das lacunas inerentes aos "tombos sofridos" no caminho da existência. "Converter-se então não significa sair da realidade ou voltar-se 'objetivamente' para algo externo, senão reconhecer-se, re-encontrar-se, re-afirmar-se no que se está manifestando na única realidade autêntica e verdadeira que se é." (TORRES QUEIRUGA, 2010b, p. 162).

Pela hermenêutica do amor o ser humano, sabendo-se criado por puro amor, deparar-se-á para a sua origem no amor. A partir de então, as suas ações só poderão mesmo é serem pautadas por esse amor.

\begin{abstract}
O que deve vir à luz por intermédio da parteira é o amor de Deus que está sempre aí sustentando/salvando sua criação. O exercício obstetrício precisa ser bem dirigido para que venha à luz a verdade. Uma hermenêutica do amor possibilita à maiêutica histórica a efetividade de seus esforços, pois só a lógica do amor conduz ao amor. Qualquer outra hermenêutica, literalista ou criticista, que compreenda a verdade como pura objetividade doutrinária ou científica não pode servir à maiêutica histórica. (ROCHA, 2010, p. 268).
\end{abstract}

Assim, o fiel crente reencontra-se e se reafirma enquanto humano e dedicarse-á a fazer o bem, sabendo-se no mundo a partir do Deus Criador. Abdica de qualquer possibilidade imediata de mal que tente desviá-lo da sua teleologia. O olhar sobre a percepção de Deus, habilitada pela hermenêutica do amor, capacita assim o ser humano a fim de fixar o seu foco nas virtudes, não nas limitações. A partir disso, o fiel sabe que toda virtude deve ser potencializada e toda limitação descartada. A hermenêutica do amor tem papel relevante no amadurecimento do ser humano a fim de que possa lidar tranquilamente "com o mistério do próprio surgimento da revelação. Esse altíssimo segredo, onde o espírito humano é fecundado para gerar aquilo que com temor e tremor nos atrevemos chamar de "palavra de Deus." (TORRES QUEIRUGA, 2010b, p. 164). Na maiêutica histórica, a hermenêutica do amor encontra a sua grande aliada. Juntas, podem potencializar ou empoderar o fiel para ter um olhar devotado sobre a revelação que seja dirigida sempre à ótica da realização humana. Desse modo, o papel obstétrico da maiêutica histórica será muito mais facilitador. O humano, instruído assim, entenderá que o 
"Deus que cria por amor, e tudo em sua criação visa o bem e a realização de sua criatura." (ROCHA, 2010, p. 268).

Entende-se, assim, que há um divisor de águas na questão da percepção da revelação de Deus a partir da maiêutica histórica maturada pela hermenêutica do amor, presente na obra de Torres Queiruga. “Deus longe de parecer um 'estranho em nossa casa' é o Goel, o advogado da causa humana num mundo atormentado pelo sofrimento individual e pela tragédia coletiva." (TORRES QUEIRUGA, 2016c, p. 99). A sua literatura insere, pois, um novo olhar sobre a fé e traz para a realidade da revelação vigor e expectativas novas para a percepção de Deus hoje. Até então, parecia incompatível um diálogo franco entre revelação divina, liberdade e autonomia humana. Eram realidades que não se conversavam entre si e daí a causa de tão grande ateísmo no mundo de hoje (TORRES QUEIRUGA, 1993). Com a literatura queiruguiana, necessariamente, entende-se que não há mais espaço para concorrência e/ou paradoxo, mas sim complementaridade e convite a uma maneira nova de o ser humano estar no mundo em paz com Deus.

A revelação de Deus funda a liberdade humana em sua expressão mais plena. Não há concorrência de liberdades - divina e humana - mas constituição e confirmação do encontro ativo de liberdades, que permite uma maneira nova do homem estar presente na história. (ROCHA, 2010, p. 269).

Assim, a hermenêutica do amor potencializa o fiel cristão para uma vivência autêntica na história. A literatura queiruguiana ressalta que o ser humano é desafiado a testemunhar com liberdade a sua experiência do amor de Deus. Sendo assim, entende-se que o encontro das duas liberdades, divina e humana, só poderá fazer com que o humano realmente assuma o seu lugar no mundo a partir da percepção de um Deus amor. Ele faz com que a humanidade se torne cada vez mais parábola viva do Evangelho, cujo Cristo é o seu protótipo por excelência, tendo na sua Cruz redentora a síntese desse processo. A cruz é uma escola, uma cátedra de que o Redentor fala, "fazendo arder o coração e abrir os nossos olhos" (Lc 24,32). De posse dessa concepção, seguindo o exemplo do Peregrino que caminhou com os discípulos de Emaús, é fácil deduzir que o ser humano tornar-se-á um mediador 
apaixonado desse trabalho maiêutico da manifestação de Deus que cria, revela e salva.

A partir de então, percebe-se um Deus não mais como um ser distante e indiferente, mas como Aquele que cria salvando, estando Ele absolutamente dedicado à salvação. E, ao salvar, acaba revelando-se continuamente. A hermenêutica do amor, na seara da maiêutica histórica, possibilita ao ser humano uma visão de fé que não admite mais imaturidade. Nesse sentido, ressalta-se que:

Podemos acrescentar a urgência de uma formação cristã adulta (pois a infantil é presa fácil da ciência moderna) que forneça internamente o quadro interpretativo cristão ausente da sociedade. Esta só poderá resultar numa fé realmente vivida se for oxigenada por um compromisso de vida. Não só missionário, como lucidamente afirma o Documento de Aparecida, mas em todo envolvimento concreto pelo outro mais necessitado ou excluído como concretização do amor fraterno e confirmação de uma fé não teórica, mas que chegue à vida. (MIRANDA, 2009, p. 133).

Essa constatação endossa o entendimento de que a hermenêutica do amor proporciona a aterrissagem da hermenêutica histórica na práxis eclesial como ponto de convergência, exigidas no Magistério de Francisco. Ela reivindica uma compreensão de que a percepção de Deus será tanto mais eficiente quanto mais possibilitar ao fiel dedicar-se aos menos favorecidos, por quem Deus tem a sua predileção. Pelo que se percebe, ainda se está longe de atingir esse ideal, na atual conjuntura, pois “a teologia na Modernidade está marcada por uma viva tensão entre as tentativas de renovação e as resistências à mesma. " (TORRES QUEIRUGA, 2016a, p. 27).

\section{Considerações finais}

As mudanças dos tempos em que coube viver a sociedade hodierna ganham configuração peculiar. Atualmente há, paradoxalmente, uma confluência de mentalidade e ao mesmo tempo uma dissonância de valores. Entende-se que, por se tratar de uma questão sempre atual, os caminhos mais eficientes para a comunicação de Deus hoje perpassam pelo processo de eficiência na comunicação da genuína imagem de Deus que Jesus veio revelar. Isso perpassa pelos desafios 
inerentes à comunicação das experiências de revelação de Deus de forma tematizada. Argumenta-se que, a linguagem de Deus inevitavelmente deve estar atrelada à práxis pastoral renovadora. Isto é, implica a realidade de cada comunidade eclesial, circunscrita na sociedade hodierna, irreversivelmente plural no imaginário social.

Desse modo, reivindica-se da teoria da revelação divina um eficiente debruçar sobre as questões acerca dos macetes da revelação divina, como os da clara linguagem e imagem para que aconteça a acolhida empática da mensagem revelada. Essa sempre reivindicará um aprofundamento mais apurado sobre o como perceber Deus. Diante disso, se se voltar tanto para os desafios e o entusiasmo da obra de Torres Queiruga, especificamente na sua teologia da revelação, que se deu na receptividade do Vaticano II, quanto para o entusiasmo do Magistério de Francisco. É assim que se depara atualmente com a necessidade de um esmerando esforço e criatividade para fazer reverberar o espírito acolhedor do Mistério revelado para a Igreja Universal. Entende-se que a quem captou o mesmo Espírito presente em todos os tempos e lugares ao longo da história da revelação, não poderia ter outra preocupação senão fomentar uma evangelização em saída e em contínua reforma, pois que essa acontece no dinamismo das culturas.

\section{REFERÊNCIAS}

BINGEMER, M. C. L. O mistério e o mundo: paixão por Deus em tempos de descrença. Rio de Janeiro: Rocco, 2013.

COMPÊNDIO DO CONCÍLIO VATICANO II. Constituição dogmática Dei Verbum: sobre a revelação divina; Constituição Pastoral Gaudium et Spes: sobre a Igreja no mundo de hoje. Petrópolis, RJ: Vozes, 1987.

CONSELHO EPISCOPAL LATINO-AMERICANO. Documentos do CELAM: Conclusões da conferência, de Medellín. São Paulo: Paulus, 2005.

FRANCISCO. Laudato si: sobre o cuidado da casa comum. São Paulo: Paulus/Loyola, 2015a.

FRANCISCO. Misericordiae vultus. São Paulo: Paulus/Loyola, 2015b.

KONINGS, John. Ser cristão: fé e prática. Rio de Janeiro: Vozes, 2011. 
KUZMA, Cesar. Fazer teologia em tempos de crise. Instituto Humanitas Unisinos. 2016. Disponível em: http://www.ihu.unisinos.br/562116-fazer-teologia-em-tempos-decrise. Acesso em: 09 nov. 2016.

MERTON, Thomas. Na liberdade da solidão. Tradução da Companhia da Viagem. 7. ed. Rio de Janeiro: Vozes, 2014.

MESTERS, Carlos. Curso bíblico 1. São Paulo: Centro de Estudos Bíblicos, s/d.

MIRANDA, Mário de França. A Igreja numa sociedade fragmentada: escritos eclesiológicos. São Paulo: Loyola, 2006.

MIRANDA, Mário de França. A Igreja que somos nós. São Paulo: Paulinas, 2013.

MIRANDA, Mário de França. Igreja e Sociedade. São Paulo: Paulinas, 2009.

NOBRE, J. A. A revelação divina hoje: uma percepção do agir de Deus na história a partir do pensamento de Andrés Torres Queiruga. Rio de Janeiro, 2017. Tese (Doutorado em Teologia) - Pontifícia Universidade Católica do Rio de Janeiro.

NOBRE, J. A; MENDONÇA, S. Anísio Teixeira e a Educação Democrática e pública de qualidade: reflexões acerca das implicações da gestão educacional. Educação em revista, Marília, v. 17, n. 2, p. 25-44, jul./dez. 2016.

NOVA BÍBLIA PASTORAL, São Paulo: Paulos, 2014.

OTTAVIANI, E. Construção histórica de Medellín. In: CONFERÊNCIA NACIONAL DOS BISPOS DO BRASIL. Liturgia e profecia: 50 Anos de Medellín. Brasília: Edições CNBB, 2017.

PALÁCIO, Carlos. O cristianismo na América Latina: discernir o presente para prepara o futuro. Perspectiva Teológica, Belo Horizonte, n. 36, p. 173-196, 2004.

PASSOS, Décio. As reformas do Papa Francisco: conjuntura, significados e perspectivas. Perspectiva teológica, Belo Horizonte, v. 49, n. 2, p. 353-374, jan./abr. 2017.

ROCHA, Alessandro Rodrigues. Experiência e discernimento: recepção da Palavra numa cultura pós-moderna. São Paulo: Fonte Editorial, 2010.

SIZA, Rita. Em Medellín, papa insiste na reconciliação e na abertura ao outro. Público.pt, 2017. Disponível em: https://www.publico.pt/2017/09/o9/mundo/noticia/em-medellinpapa-insiste-na-reconciliacao-e-na-abertura-ao-outro-1784924. Acesso em: 16 dez. 2017.

SUESS, Paulo. Sinais dos tempos. In: PASSOS, João Décio; SANCHEZ, Wagner Lopes. Dicionário do Concílio Vaticano II. São Paulo: Paulus, 2015. p. 895-901.

TORRES QUEIRUGA, A. A tarefa da teologia após a restauração pós-conciliar. Concilium, Petrópolis, n. 364, p. 26-37, 2016 a. 
TORRES QUEIRUGA, A. A linguaxe relixiosa: desmitoloxización e cambio cultural.

Encrucillada, Santiago de Compostela, v. 40, n. 198, p. 5-16, 2016b.

TORRES QUEIRUGA, A. A teologia a partir da modernidade. In: NEUTZLING, Inácio. A teologia na universidade contemporânea. Porto Alegre: Editora Unisinos, 2005. p. 47-83.

TORRES QUEIRUGA, A. Alguien así esl el Dios em quien yo creo. Madrid: Editorial Trotta,2013.

TORRES QUEIRUGA, A. Ateísmo e imagem Cristã de Deus. Concilium, Petrópolis, n. 337, p. 42-54, 2010 .

TORRES QUEIRUGA, A. Autocompreensão cristã: diálogo das religiões. Tradução de José Alfonso Beraldin da Silva. São Paulo: Paulinas, 2007.

TORRES QUEIRUGA, A. Creio em Deus Pai: o Deus de Jesus como afirmação plena do humano. Tradução de I. F. L. Ferreira. São Paulo: Paulus, 1993.

TORRES QUEIRUGA, A. Creio em Deus Pai: o Deus de Jesus como afirmação plena do humano. 2. ed. Estella (Navarra): Editorial Verbo Divino, 2000.

TORRES QUEIRUGA, A. Fim do cristianismo pré-moderno: desafios para um novo horizonte. Tradução de Afonso Maria Ligorio Soares. São Paulo: Paulus, 2003.

TORRES QUEIRUGA, A. Repensar a revelação: a revelação divina na realização humana. Tradução de Alfonso Maria Ligorio Soares. São Paulo: Paulinas. 2010.

TORRES QUEIRUGA, A. Repensar a teodiceia: o dilema de Epicuro e o mito do mundosem-males. Concilium, Petrópolis, n. 366, p. 87-99, $2016 \mathrm{c}$.

XAVIER, Donizete José. Teologia fundamental. São Paulo: Vozes, 2021. 